\title{
AGE AND TERRITORY-QUALITY EFFECTS ON FECUNDITY IN THE SPANISH IMPERIAL EAGLE (AQUILA ADALBERTI)
}

\author{
Miguel FerRer ${ }^{1}$ AND IsABelle Bisson ${ }^{2}$ \\ Estación Biológica de Doñana, Consejo Superior de Investigaciones Cientificas, Avd. María Luisa, \\ Pabellón del Perú 41013 Sevilla, Spain
}

\begin{abstract}
Over a period of 19 years, we studied 237 breeding attempts of Spanish Imperial Eagles (Aquila adalberti) in Doñana National Park (southwestern Spain), including 29 pairs with at least one immature member, to investigate age-related effects on population fecundity. Without considering effect of territory quality, adult pairs were significantly more productive than immature pairs. Highly significant differences in breeding performance among territories were independent of age-classes of birds occupying them. Low-quality territories were more frequently occupied by immature pairs, whereas high-quality territories were occupied mostly or exclusively by adult birds. Therefore, age and territory quality appear to be interrelated. We found no effect on average population fecundity due to breeding by immature pairs. Received 13 November 2001, accepted 26 October 2002.
\end{abstract}

Resumen.-Para estudiar los efectos relacionados con la edad sobre la fecundidad de la población de Aguilas Imperiales Ibéricas (Aquila adalberti) en el Parque Naconal de Doñana (SO España), analizamos 237 intentos de nidificación, incluyendo 29 de parejas con al menos un miembro inmaduro, a lo largo de un periodo de 19 años. Sin considerar el efecto de la calidad de territorio, las parejas de adultos fueron significativamente más productivas que las parejas con inmaduros. Las diferencias altamente significativas en los resultados reproductivos entre territorios fueron independientes de la clase de edad de los individuos que los ocupaban. Los territorios de baja calidad eran mas frecuentemente ocupados por parejas con inmaduros, mientras que los territorios de alta calidad fueron ocupados mayoritaria o exclusivamente por aves adultas. Por tanto, la edad y la calidad del territorio estan interrelacionadas. No encontramos ningun efecto de la nidificación de inmaduros sobre la fecundidad media de la población.

STUDIES OF age-related parental changes in reproductive success of many avian species have shown that older individuals nest earlier in the season, produce larger clutches, and have greater fledging success than do younger conspecific individuals (Newton 1979, Sæther 1990, Wooller et al. 1990, Hamer and Furness 1991, Sydeman et al. 1991, Desroschers 1992, Hepp and Kennamer 1993, Forslund and Pärt 1995). Understanding how age influences breeding success is important to studies of population dynamics and to our understanding of the relationship between habitat and productivity.

The Spanish Imperial Eagle (Aquila adalberti) is the most endangered bird of prey in Europe and one of the rarest raptors in the world (Collar and Andrew 1988). The world population is estimated to be 130 pairs (Ferrer

\footnotetext{
${ }^{1}$ E-mail: mferrer@ebd.csic.es

${ }^{2}$ Present address: Avian Science and Conservation Centre, McGill University, 21111 Lakeshore Road, Ste. Anne-de-Bellevue, Montreal, Québec H9X 3V9, Canada.
}

1993a). The Spanish Imperial Eagle population at Doñana National Park consists of 15-16 pairs breeding at a high density (occupying 20,000 ha of available habitat inside the national park with a mean territory size of 1,200 ha; Ferrer 1993b). Typically, breeding pairs include two adults, but some pairs have one or two members that have not attained adult plumage $(<5$ years old; see below) (Valverde 1960, Ferrer and Calderón 1990). Breeding of nonadult birds has been interpreted as a consequence of high adult mortality in the population and an increase in the number of vacancies (Steenhof et al. 1983, Newton 1992). One outcome of the replacement of adults with immature birds could be a reduction in the mean breeding success of the population as compared to breeding success of the same population with all breeding birds being adults.

In territorial birds, territory quality is likely to differ greatly among pairs (Newton 1979, 1991; Högstedt 1980; Ferrer and Donázar 1996). Immature birds tend to occupy low-quality territories (Newton et al. 1981, Steenhof et al. 
1983), so it is possible that habitat quality may generate age-related differences in reproductive success. The specific goal of this study was to investigate age-related differences in fecundity in the Spanish Imperial Eagle and its effects on the population of the Doñana National Park, considering territory quality as a possible confounding effect.

\section{Methods}

Study area.-The study was conducted in Doñana National Park, southwestern Spain $\left(37^{\circ} \mathrm{N}, 6^{\circ} 30^{\prime} \mathrm{W}\right)$ from 1976-1995. Three main habitats can be distinguished in the area: (1) Mediterranean scrubland, formed by Halimium spp., Cistus libanotis, Erica spp. with scattered cork oaks (Quercus suber), small stone pine (Pinus pinea) woods, and Eucalyptus spp. plantations; (2) marsh, mainly covered by Scirpus spp., flooded in winter and dry in summer; and (3) coastal sand dunes, with vegetation mainly made up of Ammophila arenaria, Corema album, and Juniperus phoenicia. The climate is Mediterranean with an Atlantic influence.

The species.-The Spanish Imperial Eagle is a large (2500-3500 g), sedentary and territorial bird of prey, with a low reproductive rate $(0.75$ chicks per pair per year), a four to five year immature phase, and a estimated longevity of 21-22 years (Ferrer and Calderón 1990). The Spanish Imperial Eagle may be divided into three easily distinguishable plumage classes: (1) juvenile, with a tawny-colored plumage that remains until the bird is 3 years old; (2) subadult, with dark patches over a tawny base, present in 4-5 year old birds; and (3) adult, predominantly dun-colored with characteristic white markings present in birds from the age of 5 years or older.

Paired birds are territorial. Territories are areas of exclusive use that are vigorously defended throughout the year. In contrast, immature unpaired eagles are not territorial (Ferrer 1993b) and move between temporary settling areas, including the natal population area, throughout the dispersal period (Ferrer 1993c).

Data and statistical analyses.-We used data from the Doñana archives for 1976-1995, a period during which the population remained stable (Ferrer and Donázar 1996) and visits to nests was made with an identical pattern of visitation to all nests in all years. Visits were performed by two or three people, one of whom climbed to the nest to record breeding stage and examine eggs or young. Nesting attempts were monitored three times during the breeding season (February-September): once at stages of egg laying, nestling, and fledgling (when the nestling reached at least 50 days of age, the age of banding). We considered laying date, number of eggs, number of nestlings, and number of chicks fledged as measures of reproductive performance. The entire national park area was surveyed at the beginning of each breeding season (January-February, during the courtship and nest-site selection period) to determine if pairs were present on territories. In summary, we knew population size, number of pairs that started reproduction, and productivity for 19 years.

A total of 237 nesting attempts occurred in the park during the 19 years. We mapped 16 territories where all nest locations had been plotted for the 19 years. A territory was an area with a high concentration of known nest locations for different years (Ferrer and Donázar 1996). Successive locations of different nests were considered to be in the same territory if the distance between locations was shorter than the average distance between neighboring pairs $(3.5 \mathrm{~km})$.

Due to annual variation in reproductive statistics, we adjusted clutch size, brood size, and productivity (number of fledglings) for year effects by subtracting annual means from the raw data. Corrected data are referred to as relative values. Laying date was given a numerical value by considering the earliest laying date of each year as day 1 . The variance of those measures of reproductive performance was not significantly heterogeneous over years.

Differences in quality among territories in that population has been already established (Ferrer and Donázar 1996). The most productive territories were near the marsh border, which supports the highest densities of wild rabbits (Oryctolagus cuniculus), an important prey (Ferrer 2001). Those differences have remained relatively constant since 1956 (Ferrer and Donázar 1996).

We conducted statistical analyses using the STATGRAPHICS statistical package (Manugistics 1992), and BMDP (Dixon and Brown 1983). We tested for differences in reproductive parameters between age classes and among territories using analyses of variance (ANOVA). To avoid potential pseudoreplication due to the high potential for strong site- and pair-fidelity in this long-lived species, two-way analyses of variance with repeated measures (BMDP 3V; Dixon and Brown 1983) were conducted. We used a restricted maximum-likelihood approach to the fixed and random coefficients model. To remove effect of age, we conducted ANOVA for adult-adult pairs only. To remove effect of territory quality, we compared fecundity parameters between immature and adult pairs present on the same territory with a nonparametric Wilcoxon signed-rank test for pooled data for the 10 territories occupied by at least one immature pair. We also compared both types of pairs separately for each of the 10 territories using Kruskal-Wallis tests. We tested for trends with linear analysis using $F$ ratio statistic to test if slope was significantly different than zero. Variances of the linear models were tested for homogeneity using Cochran's C statistic. 


\section{Results}

Age classes composition.-Twenty-nine of 237 breeding attempts (12\%) involved at least one immature bird (Table 1). Numbers of immature pairs present in the park increased over the 19 year study period, peaking in 1992 (Fig. 1). In that year, immature individuals formed $31 \%$ of the breeding eagles, and pairs with at least one immature bird constituted $46 \%$ of the breeding pairs. Over the 19 years, $7 \%(n=17)$ of male breeding birds were immature, and 10\% $(n=23)$ of the female breeding birds were immature. In this eagle population, seven territories $(44 \%$ of all territories) accounted for $82 \%$ of the total immature birds observed occupying territories.

Age effect on breeding performance.-Hereafter we will refer to all pairs with at least one immature member as "immature". All reproductive parameters except laying date showed significant differences between immature and adult pairs (Table 2). Although adult birds initiated nesting four days earlier than pairs with at least one immature eagle, the difference was not significant (Table 2). Age had a significant effect on number of eggs laid (immature: 1.00 eggs, adults: 2.06 eggs; Table 2), brood size (immature: 0.48 chicks, adults: 1.07 chicks; Table 2),

TABLE 1. Summary of Spanish Imperial Eagle pairs according to age. $\mathrm{M}=$ male, $\mathrm{F}=$ female.

\begin{tabular}{cccccc}
\hline Year & $\begin{array}{c}\text { Adult } \\
\text { pair }\end{array}$ & $\begin{array}{c}\text { Immature } \\
\text { pair }\end{array}$ & $\begin{array}{c}\text { M immature/ } \\
\text { F adult }\end{array}$ & $\begin{array}{c}\text { M adult/ } \\
\text { F immature }\end{array}$ & Total \\
\hline 1976 & 9 & - & - & - & 9 \\
1977 & 9 & - & - & - & 9 \\
1978 & 8 & - & - & - & 8 \\
1979 & 10 & - & - & 1 & 11 \\
1980 & 10 & - & - & - & 10 \\
1981 & 11 & 1 & - & - & 12 \\
1982 & 14 & - & - & 2 & 16 \\
1983 & 13 & - & - & 1 & 14 \\
1984 & 13 & - & - & - & 13 \\
1985 & 11 & - & 1 & 1 & 13 \\
1986 & 9 & - & 2 & 1 & 12 \\
1987 & 12 & 1 & - & - & 13 \\
1988 & 11 & - & - & 1 & 12 \\
1989 & 13 & - & - & - & 13 \\
1990 & 12 & - & - & - & 12 \\
1991 & 11 & - & 1 & 1 & 13 \\
1992 & 7 & 2 & 2 & 2 & 13 \\
1993 & 8 & 3 & - & 1 & 12 \\
1994 & 9 & 2 & - & - & 11 \\
1995 & 8 & 2 & - & 1 & 11 \\
Total & 208 & 11 & 6 & 12 & 237 \\
\hline & & & & &
\end{tabular}

and productivity (immature: 0.41 fledglings, adults: 0.88 fledglings; Table 2).

We failed to find any significant differences in reproductive parameters among pairs in which the immature individual was female, male, or both members were immature (Table 3). That result must be interpreted with caution, however, because the statistical power is low. Interestingly, pairs with immature males initiated nesting 15 days later than pairs with immature females.

Territory quality and breeding performance.Using pooled data for all breeding attempts, laying date, clutch size, brood size, and productivity differed significantly among the 16 different territories (ANOVA for repeated measures. Laying date: $F=3.08, \mathrm{df}=15$ and 108, $P<0.001$; clutch size: $F=2.19$, df $=15$ and 174, $P=0.008$; brood size: $F=2.32, \mathrm{df}=15$ and 199, $P=0.004$; productivity: $F=2.98, \mathrm{df}=$ 15 and 203, $P<0.001$ ). To remove the effect of age class, we conducted analyses considering only data from adult-adult pairs. Again, all reproductive parameters differed significantly among the 16 territories (ANOVA for repeated measures. Laying date: $F=3.05, \mathrm{df}=15$ and 98, $P<0.001$; clutch size: $F=1.93, \mathrm{df}=15$ and 150, $P=0.024$; brood size: $F=2.21, \mathrm{df}=15$ and $171, P$ $=0.007$; productivity: $F=2.89, \mathrm{df}=15$ and 175, $P<0.001)$. The highest value for reproductive parameters was found in territory number 9, with a mean clutch size of 2.75 eggs, brood size of 1.7 nestlings and productivity of 1.6 young. That territory has not been occupied by imma-

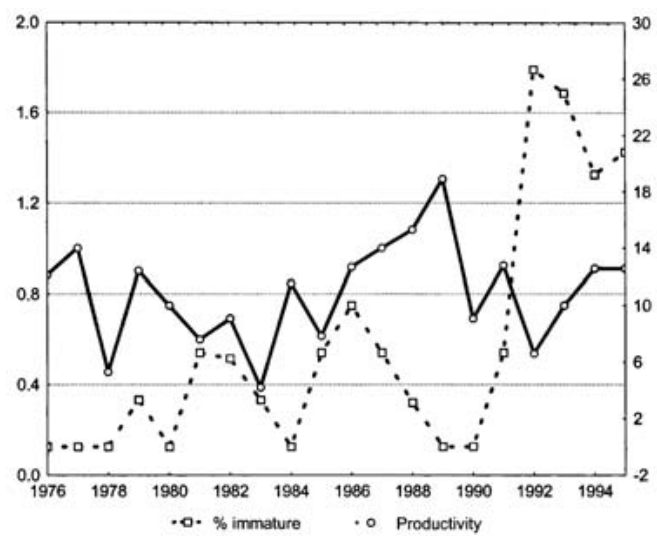

FIG. 1. Annual mean productivity of the population (left axis) and the proportion of immature individuals (right axis) in the breeding population $(r=-0.003, \mathrm{df}=$ 1 and $18, P=0.420)$. 
TABLE 2. Breeding performance, in relative values, for immature pairs versus adult pairs. (ANOVA for repeated measures).

\begin{tabular}{|c|c|c|c|c|c|c|c|}
\hline \multirow[b]{2}{*}{ Parameter } & \multicolumn{2}{|c|}{ Two adults } & \multicolumn{2}{|c|}{$\begin{array}{l}\text { At least one } \\
\text { immature }\end{array}$} & \multirow[b]{2}{*}{$F$-value } & \multirow[b]{2}{*}{$\mathrm{df}$} & \multirow[b]{2}{*}{$P$} \\
\hline & Mean & SD & Mean & SD & & & \\
\hline Laying date & -0.103 & 13.08 & 3.884 & 12.16 & 0.86 & 1 and 122 & 0.354 \\
\hline Clutch size & 0.098 & 1.124 & -0.653 & 1.180 & 9.26 & 1 and 188 & 0.002 \\
\hline Brood size & 0.070 & 1.072 & -0.398 & 0.947 & 4.79 & 1 and 213 & 0.029 \\
\hline Productivity & 0.199 & 0.972 & -0.261 & 0.840 & 5.65 & 1 and 217 & 0.018 \\
\hline
\end{tabular}

ture eagles. The lowest value has been found in territory 14 , with a mean clutch size of 0.83 eggs, brood size of 0.80 nestlings, and productivity of 0.33 young. For the 19 year period, including 18 breeding attempts, $50 \%$ of pairs that occupied that territory were immature.

During the whole study period, only 10 of 16 territories were occupied by immature birds at least once. Considering only data from adult pairs, productivity of territories correlated negatively with the proportion of immature pairs observed occupying those territories $(r=-0.623$, $\mathrm{df}=1$ and $14, P=0.009$ ).

Specific effect of age on breeding performance and population productivity.-To test for an effect of territory quality, we compared relative fecundity parameters between immature and adult pairs present on the same territory with a nonparametric Wilcoxon signed-ranks test for the 10 territories occupied by at least one immature pair. We found no further significant age-related differences in laying date, clutch size, brood size, or productivity (Table 4). Comparing adult and immature pairs separately for each of the 10 territories, using Kruskal-Wallis tests, we found no age-related differences in reproductive performances in any territory. Again, that result must be take with caution due to the small sample sizes.
Annual productivity of the population was not correlated with either proportion of immature pairs observed per year $(r=-0.335, \mathrm{df}=1$ and $18, P=0.148$ ) or with proportion of immature individuals in the breeding population $(r=$ $-0.003, \mathrm{df}=1$ and 18, $P=0.420$; Fig. 1 ).

\section{Discussion}

Age classes composition.-The proportion of immature pairs found in the Spanish Imperial Eagle population of Doñana National Park was higher than that described for other populations of large eagles (Newton 1979, Steenhof et al. 1983), but similar to the proportion found in other population of raptors (Newton et al. 1981). According to Newton (1979), nesting by immature raptors is variable and usually associated with rate of mortality among adults, as has been observed in Peregrine Falcons (Falco peregrinus; Ratcliffe 1980) and in Spanish Imperial Eagle populations elsewhere in Europe (Valverde 1960, Ferrer and Calderón 1990).

Breeding and age.-Although there are exceptions (Sæther 1990, Hepp and Kennamer 1993), age-specific differences in fecundity have been reported for many species of birds (Sæther 1990). In common with many published studies, Spanish Imperial Eagle breeding success

TABLE 3. Breeding performance, in relative values, for immature pairs grouped according to sex of the immature member. $\mathrm{M}=$ male, $\mathrm{F}=$ female.

\begin{tabular}{|c|c|c|c|c|c|c|c|c|}
\hline \multirow[b]{2}{*}{ Parameter } & \multicolumn{2}{|c|}{$\begin{array}{c}\text { M adult/ } \\
\text { F immature }\end{array}$} & \multicolumn{2}{|c|}{$\begin{array}{c}\text { M immature / } \\
\text { F adult }\end{array}$} & \multicolumn{2}{|c|}{$\begin{array}{l}\text { M immature/ } \\
\text { F immature }\end{array}$} & \multirow[b]{2}{*}{$\mathrm{K}-\mathrm{W}^{\mathrm{a}}$} & \multirow[b]{2}{*}{$P$} \\
\hline & $n$ & Mean & $n$ & Mean & $n$ & Mean & & \\
\hline Laying date & 5 & -0.117 & 2 & 14.920 & 3 & 8.530 & 5.74 & 0.125 \\
\hline Clutch size & 10 & -0.886 & 6 & -0.798 & 9 & -0.439 & 0.54 & 0.763 \\
\hline Brood size & 12 & -0.296 & 6 & -0.983 & 11 & -0.403 & 2.65 & 0.266 \\
\hline Productivity & 12 & -0.101 & 6 & -0.635 & 11 & -0.337 & 1.78 & 0.411 \\
\hline
\end{tabular}

a $\mathrm{K}-\mathrm{W}=$ Kruskal-Wallis test. 
TABLE 4. Mean values for relative reproductive parameters of adult pairs versus immature pairs occupying the same territory.

\begin{tabular}{|c|c|c|c|c|c|c|c|c|}
\hline \multirow[b]{2}{*}{ Territory } & \multicolumn{2}{|c|}{ Laying date } & \multicolumn{2}{|c|}{ Clutch size } & \multicolumn{2}{|c|}{ Brood size } & \multicolumn{2}{|c|}{ Productivity } \\
\hline & Adult & Immature & Adult & Immature & Adult & Immature & Adult & Immature \\
\hline 1 & 8.57 & - & -0.65 & -0.57 & 0.02 & -0.86 & 0.01 & -0.69 \\
\hline 2 & 13.97 & - & 0.14 & 0.00 & 0.23 & -1.00 & 0.33 & -0.62 \\
\hline 4 & -5.19 & 12.92 & 0.30 & -0.57 & 0.42 & -0.75 & 0.43 & 0.46 \\
\hline 7 & 0.00 & 16.92 & -0.07 & -0.71 & 0.16 & -0.97 & 0.50 & -0.69 \\
\hline 8 & 3.45 & 1.72 & -0.21 & 1.03 & -1.21 & 0.71 & -0.93 & 0.55 \\
\hline 10 & 2.56 & - & -0.36 & -0.01 & -0.23 & 1.30 & 0.20 & -0.75 \\
\hline 11 & -1.83 & -3.08 & 0.08 & -0.58 & -0.19 & -1.33 & -0.73 & -0.03 \\
\hline 12 & 6.85 & 22.15 & 0.65 & -0.97 & -0.87 & -0.64 & -0.14 & -0.54 \\
\hline 14 & 10.05 & 0.69 & -1.36 & -1.36 & -0.24 & -0.47 & -0.38 & -0.23 \\
\hline 15 & -2.46 & 0.40 & 0.38 & -1.92 & 0.85 & 0.56 & 1.04 & 0.37 \\
\hline \multirow[t]{2}{*}{$\mathrm{W}^{\mathrm{a}}$} & Z & $P$ & Z & $P$ & Z & $P$ & Z & $P$ \\
\hline & 1.267 & 0.204 & 1.421 & 0.155 & 1.070 & 0.284 & 0.968 & 0.332 \\
\hline
\end{tabular}

a $\mathrm{W}=$ Wilcoxon signed-ranks test.

increased significantly with age. Adult pairs had a significantly higher success in all but one reproductive parameter as compared to immature pairs. That trend has been explained by an improvement in skills with age (i.e. constraint hypothesis; Curio 1983, Nol and Smith 1987, Partridge 1989), an increased reproductive effort as a response to decreasing residual reproductive value (i.e. restraint hypothesis; Williams 1966, Gadgil and Bossert 1970, Pianka and Parker 1975, Charlesworth 1980) or both. Also, due to the potentially strong pair fidelity, mate familiarity could lead to earlier breeding and higher productivity (Sæther 1990, Woodard and Murphy 1999).

Breeding and territory.-Significant differences in fecundity parameters among territories or breeding sites have been reported for some bird species (Newton and Marquiss 1976, Woller and Coulson 1977, Högstedt 1980, Newton et al. 1981, Steenhof et al. 1983, Dhondt et al. 1992, Kempenaers and Dhondt 1992, Ferrer and Donázar 1996). Spanish Imperial Eagle breeding performance varied significantly among territories. Territories differed in distance to the marsh border, which supports the highest densities of wild rabbits, which are staple prey for eagles (see Ferrer and Donázar 1996). Territories near the marsh border had significantly higher success in all reproductive parameters compared with other territories (not only higher means but also lower coefficient of variation, see Ferrer and Donázar 1996). Territories differed significantly in laying date, clutch size, number of nestlings, and number of fledged young (also in nutritional condition of nestlings, Ferrer 1994). Furthermore, those important differences remained highly significant when only adult pairs were considered. Thus, differences among territories seem to be independent from age-classes occupying them. However, we can not exclude the possibility that low-quality adult birds ended up breeding on low-quality territories.

Considering only data from adult pairs, productivity of territories showed a negative relationship with proportion of immature pairs observed occupying those territories. Thus, low-quality territories were occupied more frequently by immature pairs, whereas highquality territories were occupied mostly or exclusively by adult individuals. Consequently, territory effect is an important component that must be removed before any analyses of age-related fecundity.

Specific effect of age on breeding and population fecundity.-We found no significant age-related differences in reproductive performance after we removed effect of territory quality from the analysis. However, those results must be interpreted with caution due to the small sample sizes when we compared reproductive parameters between adult and immature pairs for each of the 10 territories.

We suggest that it may be more likely to detect age-specific differences in breeding performance if we do not separate effects of territory and breeding-site quality from age, variables that may be highly correlated. In fact, we found a highly significant age-related difference when we did not consider effect of territory. The as- 
sumption of populations being homogeneous, instead of heterogeneous and spatially structured, can lead to important misinterpretations (Dutilleul 1993). Furthermore, territory quality is not the only confounding factor. The role of individual or pair quality must be equally addressed before any analysis of age-related changes in fecundity due to the potential effect of individual-specific differences in reproductive success. In fact, territory quality that we analyzed here is likely to be a composite of site and bird quality.

In this Spanish Imperial Eagle population, the relevant question is not why adult individuals perform better than immature ones, but why immature pairs appear more frequently than adult pairs in low-quality territories. As we have seen, the observed situation could be explained by only two assumptions: (1) breeding performances differ among territories, and (2) turnover rates by either mortality or emigration differ among territories. In that situation-that is, in a spatially structured population-frequency of occupancy by immature pairs was negatively related to territory quality, and, consequently, apparent age-related differences in breeding performances could be detected.

Unpaired immature Spanish Imperial Eagles spend only a fraction of the year in the same area as the reproductive population, and most of the time in temporary settlement areas $>90$ $\mathrm{km}$ away from the neareast nest sites (Ferrer 1993c). Thus, a resident paired eagle could detect vacancies in high-quality territories earlier than a nonbreeding bird. We have observed several such examples in our population. For instance, we have verified how a 3 year-old radiotagged immature male was integrated as breeder in 1992, together with a female in immature plumage, in one of the territories with the lowest productivity of the population. In 1993 and when the pair of immature birds was in the middle of incubating a tree egg clutch, the male shifted to a neighboring territory that had lost its male just $24 \mathrm{~h}$ earlier. The mean productivity of the new territory was significantly higher than the first one. In 1997, the same male, already in adult plumage, replaced another male in a neighboring territory of a higher productivity, where a vacancy had occurred 36 $\mathrm{h}$ earlier. We also verified that an adult male, equipped with a radio transmitter died and its place was occupied by a neighboring male from a lower productivity territory in $<30 \mathrm{~h}$.
An improvement of territory quality with age is expected because the longer an individual stays in the population, the more likely it is to find a vacancy and migrate to a better territory. In conclusion, age-related differences in breeding performance exist in the Spanish Imperial Eagle, and at least some of those differences appear to be due to age-related differences in mean territory quality. In addition, we found no significant age-related effect in annual productivity of the population according to the proportion of immature birds in breeding pairs.

\section{ACKNOWLEDGMENTS}

We are indebted to L. García, R. Cadenas, and M. L. Chacón for helping in the field, and to I. Bustamante for helping with the English text. This article has greatly benefited from conversations and comments by K. Bildstein, G. Janss, M. N. Kochert, M. Marquiss, M. T. Murphy, I. Newton, J. L. Tella, and two anonymous referees. Support for this project was provided by FUNGESMA (Glaxo-Wellcome) and Consejo Superior de Investigaciones Cientificas.

\section{Literature Cited}

Charlesworth, B. 1980. Evolution in Age-structured Populations. Cambridge University Press, Cambridge, United Kingdom.

Collar, N. J., ANd P. Andrew. 1988. Birds to watch: The ICBP World checklist of threatened birds. International Council for Bird Preservation, Technical Publication, no. 8.

Curio, E. 1983. Why do young birds reproduce less well? Ibis 125:400-404.

DesRosChers, A. 1992. Age-related differences in reproduction by European Blackbirds: Restraint or constraint. Ecology 73:1128-1131.

Dixon, W. J., AND M. J. BROWN. 1983. BMDP Statistical Software. University of California Press, Berkeley.

Dutilleul, P. 1993. Spatial heterogeneity and the design of ecological field experiments. Ecology 74:1646-1658.

Ferrer, M. 1993a. El Aguila Imperial. Editorial Quercus. Madrid, Spain.

FERRER, M. 1993b. Reduction in hunting success and settlement strategies in young Spanish Imperial Eagles. Animal Behaviour 45:406-408.

FERRER, M. 1993c. Juvenile dispersal behaviour and natal philopatry of a long-lived raptor, the Spanish Imperial Eagle Aquila adalberti. Ibis 135:132-138.

FERrER, M. 1994. Nutritional condition of Spanish Imperial Eagle nestlings Aquila adalberti. Bird Study 41:120-123. 
Ferrer, M. 2001. The Spanish Imperial Eagle. Lynx Edicions, Barcelona, Spain.

Ferrer, M., and J. Calderón. 1990. The Spanish Imperial Eagle Aquila adalberti in Doñana National Park: A study of population dynamics. Biological Conservation 51:151-161.

Ferrer, M., AND J. A. DonÁzar. 1996. Density-dependent fecundity by habitat heterogeneity in an increasing population of Spanish Imperial Eagles. Ecology 77:69-74.

Forslund, P., AND T. PÄRT. 1995. Age and reproduction in birds: Hypotheses and tests. Trends in Ecology and Evolution 10:374-378.

GAdGIL, M., AND W. Bossert. 1970. Life historical consequences of natural selection. American Naturalist 104:1-24.

Hamer, K. C., and R. W. Furness. 1991. Age-specific breeding performance and reproductive effort in Great Skuas Catharacta skua. Journal of Animal Ecology 60:693-704.

Hepp, G. R., and R. A. Kennamer. 1993. Effects of age and experience on reproductive performance of Wood Ducks. Ecology 74:2027-2036.

HöGstedt, G. 1980. Evolution of clutch size in birds: Adaptive variation in relation to territory quality. Science 210:1148-1150.

Kempenaers, B., And A. A. Dhondt. 1992. Experimental test of an hyphothesis explaining density dependent clutch-size in tits Parus spp. Ibis 134:192-194.

MANUGISTICS. 1992. STATGRAPHICS 6.0. Statistical graphics systems. Statistical Graphics Corporation, Rockville, Maryland.

Newton, I. 1979. Population Ecology of Raptors. T. and A. D. Poyser, Berkhamsted, United Kingdom.

Newton, I. 1991. Habitat variation and population regulation in sparrowhawks. Ibis 133:76-88.

NeWTON, I. 1992. Experiments on the limitation of bird numbers by territorial behaviour. Biological Reviews of the Cambridge Philosophical Society 67:129-173.

Newton, I., AND M. MARQuiss. 1976. Occupancy and success of sparrowhawk nesting territories. Journal of Raptor Research 10:65-71.

Newton, I., M. Marquiss, And D. Moss. 1981. Age and breeding in sparrowhawks. Journal of Animal Ecology 50:839-853.
Nol, E., AND J. N. M. Smith. 1987. Effects of age and breeding experience on seasonal reproductive success in the Song Sparrow. Journal of Animal Ecology 56:301-313.

PARTRIDGE, L. 1989. Lifetime reproductive success and life-history evolution. Pages 421-440 in Lifetime Reproduction in Birds (I. Newton, Ed.). Academic Press, London.

Pianka, E. R., AND W. S. PArker. 1975. Age-specific reproductive tactics. American Naturalist 109: 453-464.

Ratcliff, D. 1980. The Peregrine Falcon. Buteo Books, Vermillion, South Dakota.

SÆTHER, B.-E. 1990. Age-specific variation in reproductive performance of birds. Current Ornithology 7:251-283.

Steenhof, K., M. N. Kochert, and J. H. Doremus. 1983. Nesting of subadult Golden Eagles in southwestern Idaho. Auk 100:743-747.

Sydeman, W. J., J. F. Penniman, T. M. Penniman, P. Pyle, and D. G. Ainley. 1991.Breeding performance in the Western Gull: Effects of parental age, timing of breeding and year in relation to food availability. Journal of Animal Ecology 60:135-149.

VAlverde, J. A. 1960. La population d'Aigles Imperiaux (Aquila heliaca adalberti) des marismas du Guadalquivir; son evolution depuis un siecle. Alauda 28:20-26.

Williams, G. C. 1966. Natural selection, the cost of reproduction and a refinement of Lack's principle. American Naturalist 100:687-690.

Woodard, J. D., And M. T. Murphy. 1999. Sex roles, parental experience and breeding success of Eastern Kingbirds. Animal Behaviour 57:105115.

Wooller, R. D., J. S. Bradley, J. J. Skira, AND D. L. SERVENTY. 1990. Reproductive success of Shorttailed Shearwaters Puffinus tenuirostris in relation to their age and breeding experience. Journal of Animal Ecology 59:161-170.

Wooller, R. D., And J. C. Coulson. 1977. Factors affecting the age of first breeding of the kittawake Rissa tridactyla. Ibis 119:339-349.

Associate Editor: M. Murphy 